\title{
Researches in Athenian and Delian Documents. I.
}

\section{By William Scott Ferguson.}

\section{The Priest of Artemis.}

The priest of Artemis for Kimon's archonship (237/6) was $\Delta \iota 0 v v \sigma 0^{-}$ $\left.\delta \omega \varrho 0 \varsigma \Sigma \eta \mu \alpha \chi_{i} \delta \eta \varsigma^{1}\right)$. Semachidai belonged to the tribe Antiochis (XII).

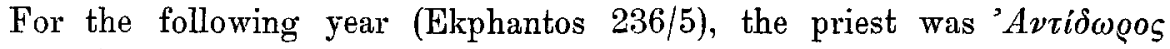

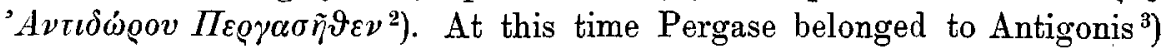
(I). The tribes of these two priests are seen thus to follow one another in the official order. Is it probable that this was the case otherwise?

Artemis Kalliste was worshipped in Athens in a shrine which lay outside the Dipylon gate, by the side of the road which led thence to the Academy ${ }^{4}$ ). She had also the epithet Ariste. Besides the two inscriptions which give us the two priests above mentioned only one other document has a reference to Kalliste. This was found by Mylonas during the excavations conducted by him in the Dipylon region in $1890^{\circ}$ ), but was

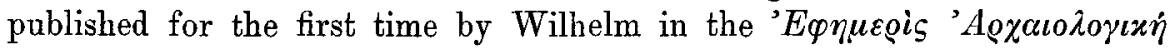
for $\left.1905^{\circ}\right)$. It yields nothing but the name. At the same time, and in the same region, however, were found two other inscriptions, now published in $\mathrm{IG} \mathrm{II}_{5} 630 \mathrm{~b}$ and $\mathrm{IG} \mathrm{II}_{5} 1620 \mathrm{e}$. Of these the first is a decree passed by the Soteriastai in honor of the founder of their club. The stone on which it was cut was placed in the temenos of the Soteira. This temenos Mylonas unwittingly found ${ }^{7}$, and in it was an altar to which belongs a bathron with the second (late) inscription: 'A

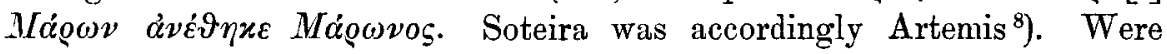
Artemis Soteira and Artemis Kalliste joined in a common cult administered by a single priest? Apparently; for the temenos of Artemis Soteira has been discovered just where Pausanias locates the shrine of Artemis Kalliste, and third century B.C. inscriptions referring to Kalliste have been found in the same vicinity with first century inscriptions re-

A. The writer begs to acknowledge the assistance received from the Carnegie Institution of Washington in the prosecution of these researches.

1) Wilhelm, 'Eq.' 'A@\%. 1905 pp. 237 ff., esp. pp、 $240 \mathrm{ff.}$ - 2) Ibid., p. 219.

3) Kirchner, Rh. Mus. 591904 pp. 294 ff. - 4) Pausanias I 292.

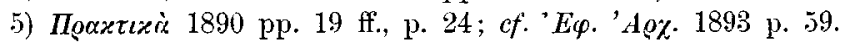

b) $\mathrm{Pp} .215$ and $220 \mathrm{ff} .-7)$ Wilhelm, ' $E \varphi . A \varphi \chi .1905$ pp. $240 \mathrm{f}$.

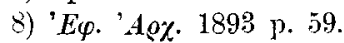


ferring to Soteira. Another document ( $\mathrm{IG} \mathrm{II} \mathrm{II}_{5} 618 \mathrm{~b}$ ), found in the same general neighborhood, refers to the temenos simply as the iego $v$ of Artemis. It is unlikely that two distinct shrines of Artemis, each tended by a state priest, were located within a stone's throw of one another.

The priest of (Artemis) Soteira in Menandros' archonship was the

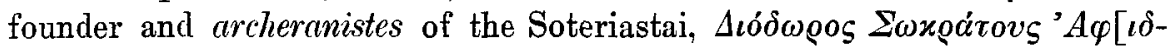
vaĩos]. Menandros was archon in 35/4 B.C., if the following calculation, made by Kirchner ${ }^{1}$ ), is conclusive. The group Euthydomos, Nikandros, Diokles of Melite, Menandros, Kallikratides, Theopeithes is inseparable ${ }^{2}$ ). Euthydomos, furthermore, was in office in the Pythian year ${ }^{3}$ ), i. e. in the third year of an Olympiad. On the other hand, in a decree of Kallikra-

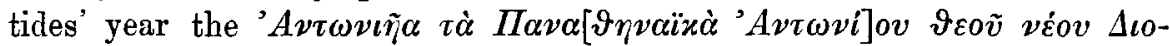
$v v \sigma o[v]$ are mentioned. This locates the fifth archon of the group in the period 39-32 B.C. ${ }^{4}$ ). These conditions make $42 / 1$ and $38 / 7$ alone possible for Euthydomos. Kirchner excludes $42 / 1$, for some reason not clear to me, and hence assigns Menandros as above stated, to $35 / 4^{5}$ ). Now, the priesthood of Asklepios was due to the tribe Ptolemais in the year $35 / 4^{6}$ ). The same tribe gave, as we see, the priest of Artemis; for Aphidnai, the deme of Diodoros, belonged to Ptolemais. Is this a mere coincidence, or did the official order exist for the priests of Artemis, and did it coincide at this time with that of the priests of Asklepios? In the middle of the third century there was no such coincidence; for, while the priesthood of Artemis fell in 237/6 and 236/5 to Antiochis and Antigonis, the priesthood of Asklepios and the prytany secretaryship fell for the same years to Antigonis and Demetrias.

The conclusions towards which the data above given tend, namely the existence of the official order for the priests of Artemis in the third and first centuries and its coincidence in the latter time with the official order of the priests of Asklepios, are far from demonstrated. They need the confirmation which the discovery of new priests can alone bring. Should they find such confirmation, then we have strengthened by accumulative evidence the assignment of the archons Kimon and Ekphantos to 237/6 and 236/5, and definitely fixed the group Euthydomos-Theopeithes in $38 / 7-33 / 2$ B.C. Are other priests of Artemis discoverable?

We have left undiscussed the lack of coincidence between the tribe of the priest of Artemis and that of the priest of Asklepios in the third century. Now we must ask the question: why was the former taken from Antiochis in 237/6 and the latter from Antigonis?

1) Rh. Mus. 531898 p. 391 n. 1. - 2) IG II 5630 b.

3) Colin. Le culte d'Apollon Pythien à Athènes pp. 143 ff. = BCH XXX 1906 pp. 304 ff.

4) Koehler, IG II 482. - 5) PA No. 5567.

6) The Priests of Asklepios (Univ. of Calif. Publ., Class. Phil. I) pp. $131 \mathrm{ff}$. 
2. The Priests of the Foreign Gods at Delos.

We get an answer through studying the tribal relations of the priests placed by Athens in the temples at Delos in the years between 167 and 88 B.C. The total list of them is as follows:

Priest of Apollo

Priest of Artemis

Priest of Zeus Kyntbios and Athena Kynthia

Priest of Dionysos

Priest of Asklepios

Priest of Roma

Priest of Hekate?

Priest of Herakles?

Priest of Anios

Priest of Sarapis

Priest of Aphrodite Hagne

Priest of the Great Deities, Dioskuri, Kabiri.

The locus classicus for these priests is the list of subscribers to the Delphian Pythaïs published in $\mathrm{IG} \Pi_{2} 985$ - a roll of officeholders for the period of the first emeeteris ${ }^{1}$ ), 103/2-95/4 B.C. All the priests did not subscribe every year: hence the omission of a title is no evidence for the non-existence of a priesthood. Thus the priest of Asklepios and the priest of the Great Deities do not appear anywhere among the subscribers. The Delian inscriptions are equally incomplete. Thus I have been unable to find the tribe and year of any priest of Artemis, Anios, Zeus Kynthios, or Roma, who held office prior to 103/2. Nor have I succeeded in ascertaining such data for two priests of Asklepios or Dionysos. Hence there is no use in studying the tribal relations of these priests now. And I omit from consideration all the other priests who belong after the year 103/2; for. as is well known ${ }^{2}$ ), the obligarchic revolution in Athens in this year was accompanied by the abandonment of allotment and rotation of office, and hence also of the official order of the tribes in the distribution of magistracies. Accordingly, all inferences from the tribal relations of the priests as shown in $\mathrm{IG}_{2}$ 985 are invalid for the earlier period of Athenian occupation of Delos.

On the other hand, we can establish the tribe and year for several of the earlier priests of Aphrodite Hagne and the Great Deities, and for the larger half of the priests of Sarapis. They are combined in the following table with the names of the Athenian archons and the Delian epimeletci ${ }^{3}$ ):

1) The reason for beginning the enneeteris in 103/2 is given in Klio IV pp. $1 \mathrm{ft}$ : cf. Dürrbach, BCH XXX pp. 294 ff. The Pythaïs had nothing to do with the Pythit; for it was certainly sent in $128 / 7$ and $97 / 6$. 97/6 was the sixth year of the enneeteris: perhaps it was arranged to send the Pythaïs regularly at that time; but probably the year within the enneeteris was not fixed.

2) The Oligarchic Revolution at Athens of the Year 103/2, Klio IV pp. $1 \mathrm{ff}$.

3) I omit such epimeletai as cannot be assigned to a precise year. 


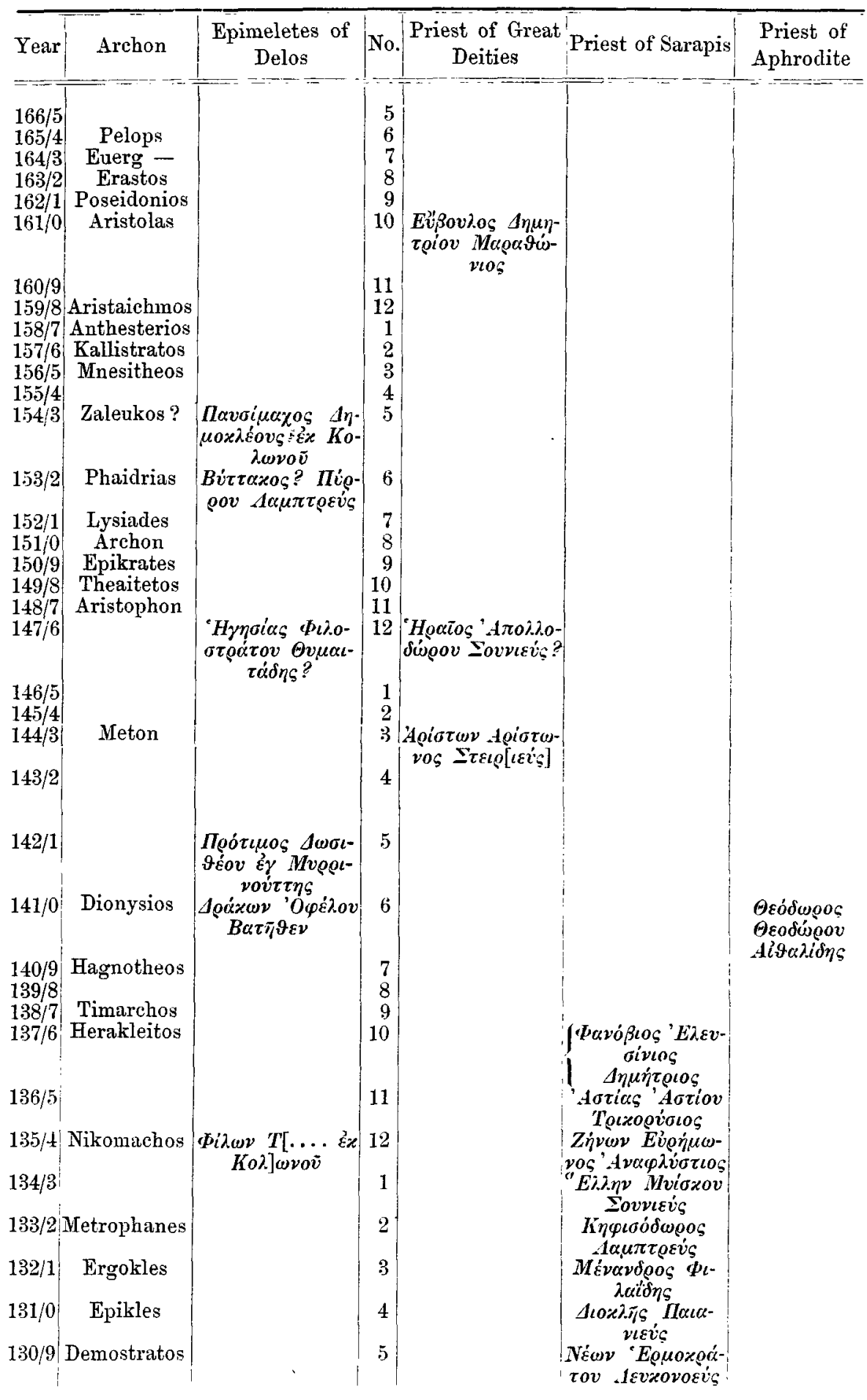


Researches in Athenian and Delian Documents. I.

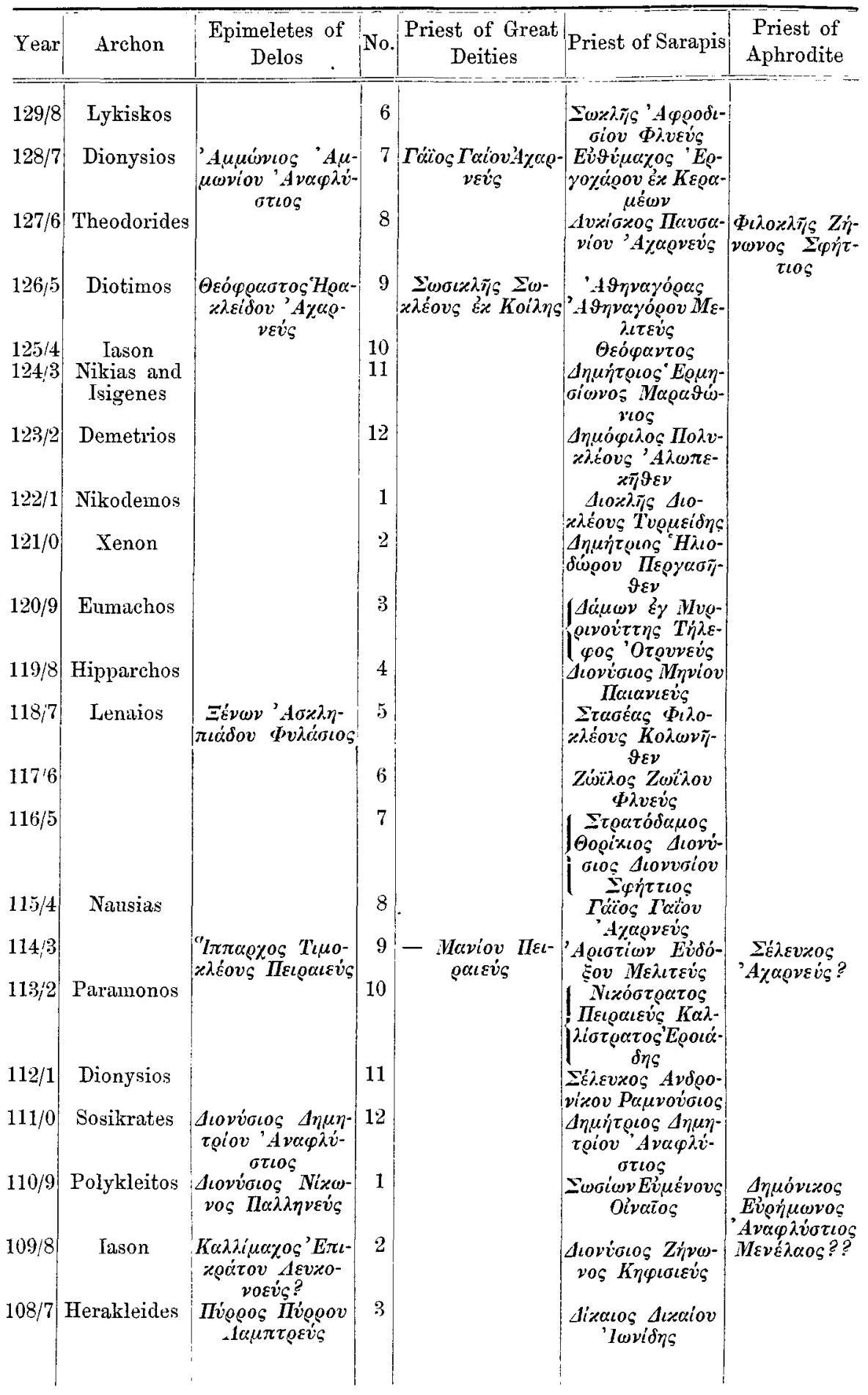




\begin{tabular}{|c|c|c|c|c|c|c|}
\hline Year & Archon & $\begin{array}{l}\text { Epimeletes of } \\
\text { Delos }\end{array}$ & No. & $\begin{array}{c}\text { Priest of Great } \\
\text { Deities }\end{array}$ & Priest of Sarapis & $\begin{array}{l}\text { Priest of } \\
\text { Aphrodite }\end{array}$ \\
\hline $107 / 6$ & Aristarchos & 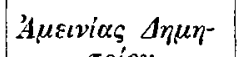 & 4 & & 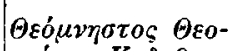 & $A<\sigma$ \\
\hline $106 / 5$ & Agathokles & & 5 & & 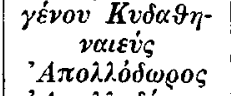 & 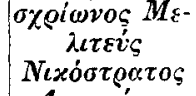 \\
\hline $105 / 4$ & Menoites & 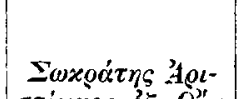 & 6 & & 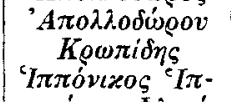 & 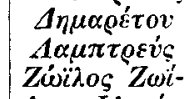 \\
\hline $104 / 3$ & Sarapion & 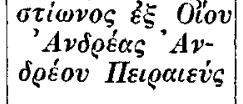 & 7 & & 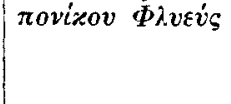 & 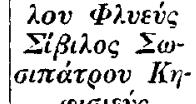 \\
\hline $103 / 2$ & & - $-\Pi \omega \iota \alpha v \iota \varepsilon \dot{v} \varsigma ?$ & & & 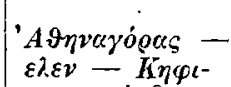 & \\
\hline $102 / 1$ & Theokles & 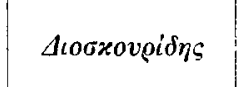 & & & 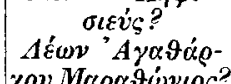 & \\
\hline $101 / 0$ & Echekrates & 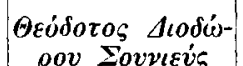 & & 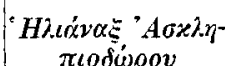 & Oov & \\
\hline $100 / 9$ & Medeios & 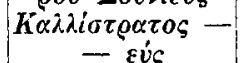 & & & Oé̉ßıos Atovv- & \\
\hline $99 / 8$ & Theodosios & 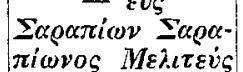 & & & & \\
\hline $98 / 7$ & Prokles & 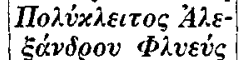 & & & 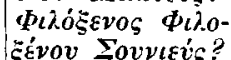 & \\
\hline $97 / 6$ & Argeios & 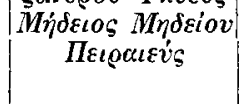 & & & 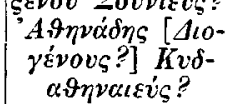 & 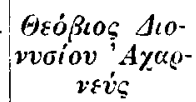 \\
\hline $6 / 5$ & Ar & & & & & \\
\hline $5 / 4$ & Herakleitos & 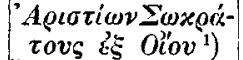 & & & 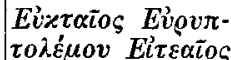 & \\
\hline $93 ; 2$ & Demochares & 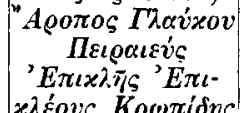 & & & 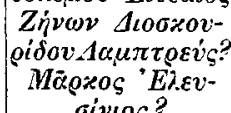 & \\
\hline $92 / 1$ & Diokles? & $\underset{0 \ell \varepsilon v \varsigma ?}{000 \varsigma, \Sigma \tau \varepsilon t}$ & & & 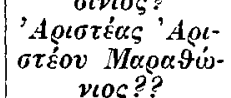 & \\
\hline $91 / 0$ & Medeios & 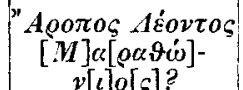 & & & 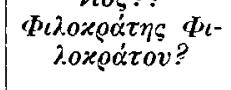 & \\
\hline $90 / 9$ & Med & & & & 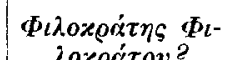 & \\
\hline $9 / 8$ & Medeios & & & & & \\
\hline
\end{tabular}

1) Von Schoeffer (De Deli insulae rebus p. 226,3) has restored IG II 985 C II 8

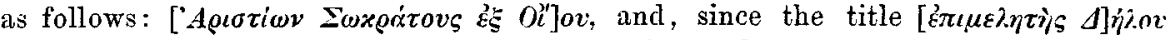
appears immediately above in line 7 , he conjectured that Aristion was governorgeneral of Delos in 98/7 (Prokles). Since we knew from the Delian documents that Polykleitos. son of Alexandros, of Phlya was epimeletes in 98/7. Homolle suggested that the latter was suffectus (BCH VIII p. 127; Kirchner, PA No. 11978).

But the priest of Zeus Kynthios for $98 / 7$ was Sarapion. son of Sotades, of Aigilia (Kirchner, PA No. 12561); while the priest for the year in which Aristion was epimeletes was.$\varepsilon \ldots \ldots \ldots \ldots \ldots$ 'A A $\ldots$ ovev́s (Loewy. Inschr. griech. Bild. No. 247). Is it thinkable that here too o ne was suffectus?

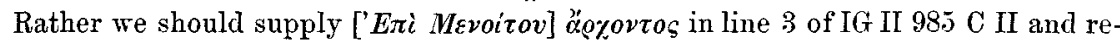
gard the officials of lines $3 \mathrm{ff}$. as belonging to 105/4. Then we should restore line 8

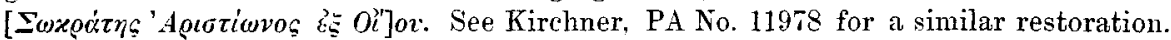


The number in the fourth column indicates the position in the official order of the tribes to which the priest of the Great Deities belonged. It does more than that, however: when reduced by one and by two it indicates the same fact for the priest of Sarapis and the priest of Aphrodite respectively. In other words, the tribe which gave the priest of the Great Deities in one year gave the priest of Sarapis in the following year, and the priest of Aphrodite in the next after that again. Of course, we do not possess data sufficient to demonstrate this relation between the three priesthoods for many years in the period 166/5-103/2. But from CIG II 2270 it results that Eubulos of Marathon was priest of the Great Deities in or about 161/0, while the location of Gaios of Acharnai in 128/7 ${ }^{1}$, and of Sosikles of Koile in 126/5 ${ }^{2}$ ), is quite certain. So, too, we know beyond a doubt that Philokles of Sphettos was priest of Aphrodite in 127/6 ${ }^{3}$ ) and Demonikos of Anaphlystos in 110/9 ${ }^{4}$ ). From these data, therefore, we are warranted in constructing a speculative scheme for the entire earlier period.

We know that the official order was abandoned in the case of the priests of Sarapis in approximately 103/2. Thus Ptolemais was due for 105/4, and Hipponikos of Phlya was priest. In 100/99 Aiantis was due, but Theobios of Acharnai was priest. The interruption had obviously occurred in the meanwhile, and in an article in the fourth volume of Klio $^{5}$ ) I have shown reasons for believing that it took place in 103/2. We do not know at what time the official order was given up for the priests of the Great Deities ${ }^{6}$ ). For the priests of Aphrodite the end came between $110 / 9$ and $107 / 6$. Thus, while Aigeis should have received this priesthood in 107/6, Aischrion of Melite was chosen ${ }^{7}$; ; and with a similar disregard of tribal rights, Nikostratos of Lamptrai and Zoïlos of Phlya succeeded one another, perhaps in $106 / 5$ and $105 / 4^{8}$ ). We are not on this account warran-

Aristion, son of Sokrates, ${ }^{2} \xi$ Oiov was the son of the epimeletes of $105 / 4$ (Kirchner, PA No. 13119). Eutychides, whose dated activity in Delos belongs to 116/5, 108/7, $106 / 5,99 / 8$ ?, was still at work in Aristion's year. Hence the father and son must have held the governor-generalship quite close together. Now, in 100/99, 96/5, and 95/4 Theobios, the son of Dionysios, of Acharnai was priest of Sarapis, Aphrodite, and Zeus Kynthios respectively. It is obvious that we have to restore the passage

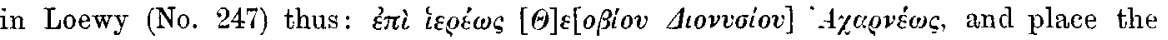
epimeleia of Aristion, son of Sokrates, of Oion in $95 / 4$.

1) $\mathrm{CIG}$ II $2296 .-2) \mathrm{BCH}$ VII p. 370.

3) BCH VI p. 347; VII p. 367; VIII p. 131, n. 2 on p. 132.

4) BCH VI p. $489 .-5)$ P. 7.

6) Since this priest does not appear at all in IG II 2 985. and since Helianax figures in c. $101 / 0$ as priest of Poseidon Aisios for life and of the Great Deities (BCH VII p. 349), it is possible that at this time annual tenure had been replaced by life tenure. - 7) 'A $\boldsymbol{9} \dot{\eta} \boldsymbol{\eta}$. IV p. 462.

8) Ibid. IV p. 460. The donor, Kleostratides, bincls Nikostratos and Zoilos to Aischrion $=107 / 6 ; c f . A \vartheta \eta v$. IV p. 461: so does the demosios. Eutychides, who is common to the three priesthoods. 
ted in doubting the maintenance of the official order for the fifty eight preceding years, the analogy of the priests of Sarapis being decisive on this point.

It thus appears that the way was left open for a man should he aspire to hold the three priesthoods in succession; for, had the same tribe received them all in the one year, a candidate could secure the three only after the lapse of twenty five years. This was objectionable, not so much, perhaps, from the disability it put upon individuals, as from the handicap it imposed upon those who were interested in the prosperity of the foreign cults. Wealthy men should be encouraged to hold the priesthoods, not debarred by restrictions, artificial at best, and quite unintelligible to orientals; for what did Syrians or Hieropolitans know of the democratic theory that all citizens should be advanced in turn to public trusts? In addition, there was a practical objection to placing unnecessary obstacles in the way of successive tenure of priesthoods. These charges belonged almost, if not quite, exclusively to the members of the Athenian settlement on Delos; for, whereas the holders of the higher insular magistracies meet us at every turn in the contemporary Athenian inscriptions, and were demonstrably sent from the capital, the priests are rarely found outside the Delian documents. Perhaps the distinction conferred by a priesthood was not sufficient to induce an Athenian to spend a year on the island, and return home feeling mean if he had not made some handsome gift to the shrine of which he had had charge. Perhaps the priesthoods were given over as perquisites to the kleruchs. At any rate the responsibility of attending to the cultus, of erecting temples, images, balustrades, exedras, and priests-houses, of paring courts and building walks and walls, of frescoing ceilings, and providing windows, doors, fountains, etc., in a word, of equipping a new and expanding precinct, fell upon the devotees of the various gods in the first instance, but very heavily also up on the shoulders of the wealthy men in the colony ; for to these the priesthoods were ordinarily left. Such men were relatively few in number. Upon this point we must not be misled by appearances. The recent proof that there were but 700 citizens in Delphi ${ }^{1}$ ) shows again that it does not take many grasshoppers to make a noisy orchestra. The Athenian kleruchy was, in fact, a small settlement, and we can be sure that there were not too many suitable men at hand each year for allotment to the priesthoods of the foreign deities. Hence the necessity of opening them in quick succession to the same person.

The reason for treating the priesthood of the Great Deities, Dioskuri, Kabiri - to give it its full title - (to which that of Poseidon Aisios was added later), the priesthood of Sarapis (to which fell the cult of Isis, Anubis, and Harpokrates), and the priesthood of Aphrodite Hagne (to which the worship of Adad and Atargatis was closely related) as a special unit was that they had as their collective function the care of all the

1) Bourguet. L'administration financière du sanctuaire Pythique pp. $44 \mathrm{f}$. 
foreign deities recognized in Delos. They had nothing to do with the Apollo-Artemis-Leto precinct and its aggregate of native shrines. To them belonged a new precinct, with a complex of temples, located on the slope of Mt. Kynthos, by the edge of the Inopos ravine, at a slight distance from the old religions centre of the island. It is possible that Herakles, i. e. Melkarth, and Asklepios were regarded as foreign deities likewise ${ }^{1}$ ), and relegated to the same region. Hence we should like to have some data for establishing the tribal relations of the priests of these deities, but unfortunately we cannot be sure that a priest of Herakles existed at all, and we can make nothing out of the few referances to the priest of Asklepios.

Since the priesthoods of the foreign gods formed a group by themselves we must not conclude that the mode of election used in their case was that employed for the other priesthoods in Delos. Here the most natural parallel is the priesthood of Asklepios in Athens itself, and the evidence at present available is quite against the use of the official order to distribute this priesthood in the second century B.C. ${ }^{2}$ ). Such is also the case for the priesthood of Apollo in Delos. To be sure, only one priest prior to $103 / 2$ can be assigned to a precise year, and this one ${ }^{3}$ ), Dionysios, son of Demetrios, of Anaphlystos (111/0) came from the same tribe as that which in this year gave the priest of Sarapis and the prytany secretary. But Ares, the son of Ares, of Kephisia was priest of Apollo in the year (147/6?) in which Heraios, son of Apollodoros, of Sunion was priest of the Great Deities ${ }^{4}$ ). Had the priest of Apollo belonged to the same tribe as the priest of Sarapis, Ares should have been registered, not in Erechtheis, but in Attalis. Hence, while the point is not definitely established, it seems most likely that the tribal order was disregarded in the selection of the priests of Apollo.

We have now answered the question with which we started our examination of the Delian priestships, and we can affirm confidently that the priest of Asklepios for 237/6 was taken from the tribe Antigonis, and the priest of Artemis from the tribe Antiochis, in order that - the arrangement of this year being taken as indicative of the general practice - it might be possible for the priests of Asklepios to offer themselves as candidates for the priesthood of Artemis in the following year. Otherwise they would have been obliged to wait for twelve years, and by that time an ambitious man was less likely to trouble himself with the petty duties of a priesthood.

3. Clironologica.

A. Aristrictmos. According as we reckon inclusively or exclusively,

1) Reinach, BCH VII pp. 333 and 366. - 2) Priests of Asklepios p. 144.

3) $\mathrm{BCH}$ XIII p. 372 ; CIG II 2298.

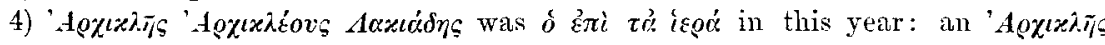
taxiód $\eta$ was hieropoios in $152 / 1$. 
the archon Aristaichmos belongs to $159 / 8$ or $160 / 59$ B.C. $\left.{ }^{1}\right)$. Since it appears that Eubulos of Marathon was priest of the Great Deities in $161 / 0$, and that he held the priesthood of Asklepios between that year and the archonship of Aristaichmos, in which he was priest of Dionysos ${ }^{2}$ ), it is necessary to assign Aristaichmos to 159/8. Prior to the tenure of his priesthoods, Eubulos had headed the theoria sent by the kleruchs to the Panathenaia, and in this capacity won for his colony the first public award of a crown. Since the Great Panathenaia are probably meant, and the summer of 166 was entirely occupied with the turmoil of settling on the island, the theoria of Eubulos should be dated in 162/1. Eubulos is a striking case of a man who sought three priesthoods in succession.

B. Meton. Meton was provisionally assigned by S. Reinach ${ }^{3}$ ) to the end of the second century, and by Kirchner to post 150. The priest of

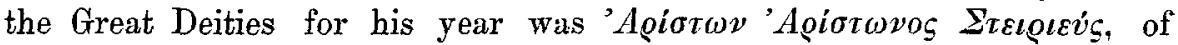
the tribe Pandionis. Pandionis held this priestship in 156/5, 144/3, 132/1, $120 / 19$, and $108 / 7$ within the period possible for Meton. Of these the only year without an archon is $144 / 3^{4}$ ).

C. Dionysios. From BCH VI p. 491 we learn the name of an archon Dionysios. From the fact that the archon for $128 / 7$ is always designated

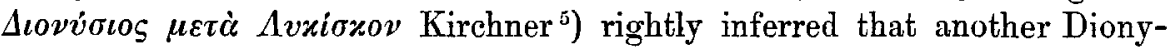
sios preceded 128/7 by a short interval. This Dionysios he found in BCH VI p. 491. The priest of Aphrodite Hagne for the archonship of Dionysios was Theodoros of Aithalidai (Leontis). Leontis had this priesthood prior to $128 / 7$ in $129 / 8,141 / 0,153 / 2$, and $165 / 4$. Of these $141 / 0$ is alone available. By dating Dionysios in $141 / 0$ we have at the same time dated the epimeletes, Drakon, son of Ophelas. of Bate, and oi $\dot{\varepsilon} \pi i$

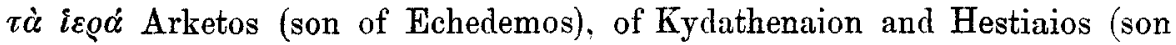

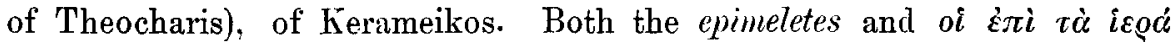
are known elsewhere. Drakon, for example, was an ephebe in Anthesterios' archonship (158/7) '). He must have been epimeletes at the age of 35. That is rather young, and it must be admitted that a later date than $141 / 0$ for Dionysios would be slightly preferable on prosopographical grounds. Thus the father of Arketos was a knight in 153/2 ${ }^{\mathrm{T}}$. He could not have had a son sufficiently mature for a Delian magistracy much earlier than 141/0. Hestiaios ${ }^{8}$ ) was subsequently hoplite-general in $99 / 8$. He too must have been quite a young man in $140^{\prime \prime}$ ).

1) Kirchner, Gött. gel. Anz. 1900 p. 462 ; cf. PA Suppl. No. 1641.

2) CIG II 2270. - 3) BCH VII p. 341. - 4) PA II p. 650. - 5) PA No. 4110.

6) IG II 445 Col. II 40. - 7) Kirehner, PA Nos. 6166 and 6165.

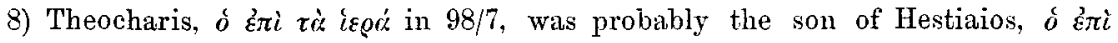
$\tau \dot{\alpha}$ igex́ in 141/0 and hoplite-general in 99/8. not. as in Kirchner PA No. 7188, identical with Theocharis, kosmetes in $119 / 8$ and herald of the Areopagos in 100/99.

9) It is probable that the office $z \pi i$ i $\tau$ í icox came early in the Athenian cursus honorum. It was rarely filled by people of whom we have knowledge in other connections. 
D. Xenon. Xenon must be transferred from where he is now placed, in the neighborhood of $135-130$ B. C. ${ }^{1}$ ), to c. 120 B. C. The paidotribes at Delos in the archonship of Xenon was Staseas, son of Philokles, of Kolone ${ }^{2}$ ). This person was the director of a palaestra on the island ${ }^{3}$ ), and as paidotribes put up a list of his ex-pupils who, while under his charge, had served as priests, agonothetai, lampadarchs, and

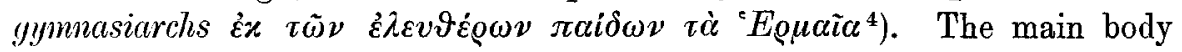
of the catalogue was compiled doubtless in Xenon's archonship; for we have no evidence that Staseas or anybody else was paidotribes in Delos twice. However, the list was not all inscribed at that time; for a supplement of five names of gymnasiarchs was put to it later ${ }^{5}$ ). The interval between the first draft and the additions was not a great one, since otherwise the catalogue would have been extended by more than five names. Now, the final draft was finished in or about the year 108/7 in the archonship of Herakleides; for among the additions are the names of Heliodoros and Dies, sons of Dies, Athenians, while among the ephebes for Herakleides' year are named the sons of Dies, Heliodoros and - $v^{\prime} \eta \varsigma$ of Tyrmeidai ${ }^{6}$ ). Heliodoros, an ephebe in $108 / 7$, was a $\pi \alpha i$ s of the competitive age $(12-19)$ between $114 / 3$ and $107 / 6$ at the outside. Hence the additions were not made prior to $114 / 3$. On the other hand, the paidotribai for Herakleides' year were Staseas and Philokles, sons of the Staseas who published the list of his prize ex-pupils. This we learn through restoring the text which Dürrbach has published in the BCH for $\left.1905^{7}\right)$. It should probably read as follows:

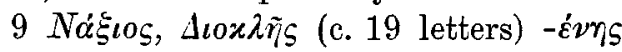

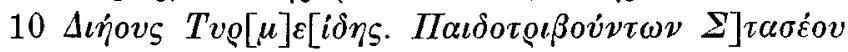

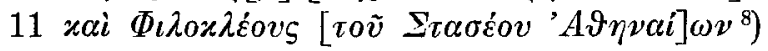

vacat

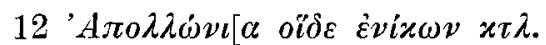

It is likely that in $108 / 7$ the sons had charge of the palaestra, their father having already died or retired. Hence Heliodoros cannot have issued from the palaestra of Staseas Sr. later than 109/8.

1) The Athenian Archons p. 73; Kirchner, PA No. 11323.

2) $\mathrm{BCH} \mathrm{XV} \mathrm{p.} 252$ and XIX p. 511. Staseas is also known from several references in the Delian graffiti BCH XIII pp. 374 ff. and especially plates XII and XIII. He was apparently an athletic hero among the youth of the island.

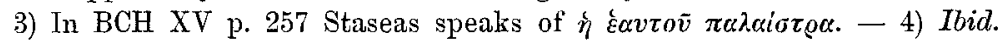

5) Fougères, BCH XV p. 25. - 6) BCH XXIX pp. 229 ff. - 7) Loc. cit.

8) This restoration demands that line 11 should be a trifle shorter than those preceding it. In favor of it we urge that it supplies the names of the paidotribai, which are not usually lacking in the Delian ephebic documents. Otherwise, the two genitives connected by zai are inexplicable. The space between lines 11 and

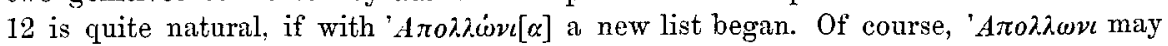

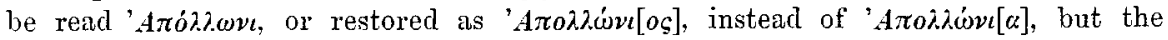
latter is probably better; $c f$. BCH XXVIII p. 146; III p. 378 . 
We shall not go far astray if we place the paidotribate of Staseas Sr. in c. 121/0 and the completion of the list about eleven years later in c. 110/9. We have, accordingly, assigned Xenon to 121/0.

This being so, Epikrates, son of Epikrates, ephebe in Xenon's year, will be the grandson of the archon of $150 / 49$, if he belongs to the same family at all. Iason, son of Selenkos, (of Paiania), ephebe in Xenon's year, will be the cousin of Seleukos, son of Jason, gymnasiarch in the list of Staseas. The colleague of Staseas in the puidotribute was Sotades of Aigilia. This will be the son of Sotades $\Sigma \omega \tau$ ádov of Aigilia, ayortanomos in Zaleukos' archonship (c. 154). His brother Sarapion was priest of Zeus Kynthios in $98 / 7$ B. C. ${ }^{1}$ ).

The archonship was ordinarily held before the epimeleia of Delos: thus Dionysios, son of Demetrios, of Anaphlystos was archon in 128/7 ${ }^{2}$ ) and epimeletes in 110/0: Hipparchos was archon in 119/8 and epimeletes $\left.114 / 3^{3}\right)$ : Dionysios was archon in $112 / 1$ and epimeletes in $110 / 9$ and Polykleitos was archon in 110/9 and epimeletes in 98/7, if, indeed, they are the same: Sarapion was archon in $104 / 3$ and epimeletes in 99/8: Medeios was archon in 100/99 and epimeletes in 97/6. So, too, Xenon, archon in 121/0, was epimeletes in 118/7. Staseas, son of Philokles, of Kolone, paidotribes in 121/0, was priest of Sarapis in 118/7. There is no difficulty anywhere.

E. Sosikrates and Herakleides. The only problem in the dating of these archons has been to decide to which two of the years $114 / 3,111 / 0$, 108/7, they belong. Thus, while I placed Herakleides in $114 / 3$ and Sosikrates in 111/0 ${ }^{4}$ ), Kirchner put them in $111 / 0$ and $108 / 7^{5}$ ), neither of us having the means of making a sharp assignment. The matter is now settled definitely. The epimeletes of Delos for 111/0 was Dionysios, son of Demetrios, of Anaphlystos ${ }^{6}$ ). From an inscription published by Dürrbach in $1905^{7}$ ) we learn that the epimeletes for Herakleides' archonship was Pyrrhos of Lamptrai. Herakleides, accordingly, was not archon in 111/0. That year should, therefore, be assigned to Sosikrates - the fact that Neon of Aphidnai was paidotribes ${ }^{8}$ ) in 108/7 and 107/6, as well as in Sosikrates' archonship, being decisive against 114/3. On the other hand. the official order locates Dikaios, son of Dikaios, of Ionidai as priest of Sarapis in $\left.108 / 7^{9}\right)$. Now Dikaios held this priestship $\dot{\varepsilon} \nu \tau \tilde{\varphi} \varepsilon\left[\varphi^{\prime} \ldots ? \varkappa \lambda \ldots o v\right.$

1) Kirchner, PA No. 12561.

2) $\mathrm{BCH} X X X$ p. 184: he was hoplite-general in 106/5 (BCH XXX p. 186).

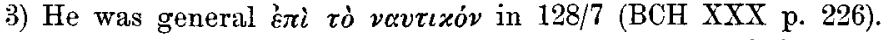

4) Cornell Studies X p. 84. - 5) PA II p. 647. - 6) CIG II 2298.

7) BCH XXIX p. 229.

8) Cornell Studies X p. 82.

9) His general neighborhood is indicated by the fact that Eutychides (116/5 = Loewy, Inschriften griech. Bildhauer No. 245 to $95 / 4=I b i d$. No. 247) was working in Delos during this priestship (Loewy, No. 244). 


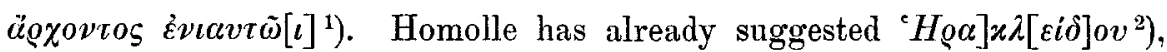
which is unquestionably right. Herakleides, consequently, belongs to 108/7.

F. Demochares. In the Athenian Archons ${ }^{3}$ ) I assigned Demochares to $108 / 7$. The prime reason for so doing was that the secretary for his archonship was from Pandionis, and 108/7 was the only year available for such a secretary in the entire neighborhood. Kirchner ${ }^{4}$ ) objected that the presentation of a peplos to Athena was made only at the time of the Great Panathenaia in the third year of an Olympiad, yet this ceremonial was completed in Demochares' archonship. This had been Koehler's opinion ${ }^{5}$ ), and August Mommsen ${ }^{6}$ ) had assented to it, in so far, at least, as the second century B. C. was concerned; but a glance at the evidence compiled by Michaelis ${ }^{\top}$ ) showed that the tradition was self contradictory on this point. Hence, notwithstanding that an elaborate memorial of the presentation, such as we have for Demochares' archonship, was natural for the quinumenniral but unnatural for the annual occasion, in Klio IV p. 10 notes 5 and $6 \mathrm{I}$ expressed my adherence to my original opinion.

Kirchner assigned Demochares to $94 / 3$, the only available third year of an Olympiad in the desired vicinity. Wilhelm, however, affirm ed that Dionysia and Hierokleia, two maidens in Demochares' year were the daughters of Asklepiades and Dionysios of $\mathrm{Phlya}^{8}$ ), who had been ephebes in 107/6. Of course boys of 18 in 107/6 could not have had daughters in 108/7. Nor could they have had daughters old enough to work on the peplos of Athena in $94 / 3$, argned Wilhelm in claiming for Demochares a date long after $94 / 3$.

$108 / 7$ is now out of the question. Demochares was archon after 103/2. We have to choose between $94 / 3$ and a much later date. But first we have to ask ourselves, how old were the women who spun Athena's peplos: The evidence is again self-contradictory "). The work was begun by two maids (arlleplioroi) not under seven nor over eleven years

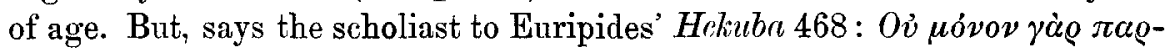

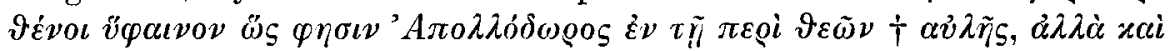

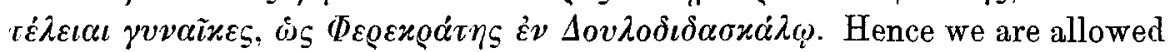

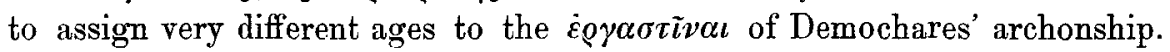

The daughters of men who were ephebes in 107/6 must have been children in $94 / 3$. On the other hand, the daughters of Hagias, son of Bulon (phylarch in 128/7 ${ }^{10}$ ), of Pyrrhos of Lamptrai (epimelete of Delos

1) Loewy, No. $244=$ Homolle, Mon. Gr. 8 (1879) pp. $39 \mathrm{ff}$. Line 3 had two letters after the one above the epsilon of ' $E\left[\varphi^{\prime}\right]$ : line 6 had $2^{1 / 2}$ and line 7 had $3^{1 / 2}$ - according to Loewy's reproduction of the stone. ' $L[\varphi$ ' ' $H \rho \alpha] x \lambda[\varepsilon i \delta] o v$ is, therefore, possible.

2) BCH XVIII p. 337. - 3) Cornell Studies X p. 85.

4) Gött. gel. Anz. 1900 p. 473. - 5) Ath. Mitt. VIII p. 62.

6) Feste der Stadt Athen pp. 112 ff. - 7) Der Parthenon p. 328.

8) Urkunden dramat. Aufführ. pp. 82 f. - 9) Michaelis. Der Parthenon p. 329.

10) BCH XXX p. 238 ; cf. pp. 255 ff. and p. 292. These new data make some changes necessary in the genealogical tree constructed by Hiller in IG XII 3 p. 286, No. 1298.

Klio, Meitrige zur alten Geschichte VII 2. 
in 108/7. herald of the Areopagos in 97/6, hor.-ite-general in 95/4 ${ }^{1}$, and of Gerostratos of Lamptrai (the father of Poseidonios, kleiduch in 106/5?, married and father of a son in $97 / 6)^{2}$ ) could have been $\tau \varepsilon \dot{\lambda} \lambda \iota \iota \iota$ yvvaix in 94/3. But since many children were usual among the upper classes in Athens at this time, we may suppose the éoyceriiva to have been the youngest of large families. But that almost all the girls we can identify among those named in the list of the ergastinai were late born, or that the workers of the peplos were habitually grown up women (they were represented by their fathers, not their husbands. both in Theokles' year and in Demochares' year ${ }^{3}$ ), are quite improbable hypotheses. But on no other supposition can we locate Demochares later than 94/3.

4. The Precinct of the Foreign Gorls. A Sarapieion ${ }^{4}$ ) and an Isieion ${ }^{5}$ ) existed in Delos before the second Athenian occupation. The location of these edifices seems to be as yet unknown. That they formed part of the cluster of buildings unearthed on the banks of the Inopos is unlikely; for in this region no dedication has been found - to my quite limited knowledge - which antedates $167 / 6$.

The history of the Inopos precinct can be made out now from the extant dedications and monuments.

The chief temple in the Sarapis-Aphrodite iqoóv - that of which the priest of Sarapis, Isis, Anubis, and Harpochrates was titular - was dedicated to Sarapis, Isis, and Anubis by the demos of Athens in 135/4 B.C. This is clear from the dedication on the architrave ${ }^{6}$ ). The second temple, distinguished in the same way ${ }^{7}$ ), was opened solemnly in 130/29. It was sacred to Anubis. The architrave of the third, which bore the

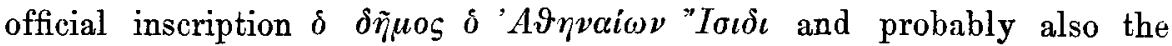
names of oi $\dot{z} \pi i \quad \dot{\alpha} i \varepsilon \varrho \dot{\alpha}$, shows that the formal dedication took place in $\left.128 / 7^{8}\right)$. This was the temple of Isis. In the same year in which this building was accepted by the people of Athens, Achaios, son of Apollonios, a Hieropolitan dedicated a temple, a building adjoining it, and some little altars to his native deities Adad and Atargatis. Associated with him in making the gift were his wife Eubula. his five children, and his three brothers. The eity of Hieropolis sanctioned the donation, and perhaps the people of Athens formally accepted it, but no priest was designated by Athens for Adad and Atargatis, and the synod of the Hieropolitans on the island chose one of their own number annually to administer the cult ${ }^{9}$ ). The fifth temple was seemingly the gift of the priest of Aphrodite ${ }^{10}$ ) for $127 / 6$, and was dedicated by him in that year. It was

1) BCH XXIX p. 229; Kirchner, PA No. 12520.

2) BCH VI p. 346 ; XXIX p. 234 n. 1. - 3) IG II 477 and IG II $5477 \mathrm{~d}$.

4) BCH VI pp. 20, 24, 27, 52; XXVIII p. 159. - 5) BCH VI pp. 27, 52.

6) BCH XVI p. 481 . - 7) BCH VI p. 340 No. 48.

8) BCH VI p. 334 No. 32. - 9) BCH VI p. 49. No. 12 ; cf. also p. 496 No. 13.

10) BCH VI p. 347 No. 68; VII p. 367; VIII p. 131 n. 2 (on page 132). 
sacred to Aphrodite Hagne, and, unlike those of Isis and Anubis, it had its own priest and cult.

The sixth temple (vaós is the word invariably used) was a gift of Nikomedes II of Bithynia ${ }^{1}$ ). It was sacred to Isis Nemesis, and was dedicated by the priest of Sarapis in 110/9. It contained a statue of this goddess, and is probably to be identified with the little edifice placed on the heights behind the portirm ${ }^{2}$ ) marked RS on the plan of HauvetteBesnault ${ }^{3}$ ). The statue has been found and described by Hauvette-Besnault in the Bulletin for $1882^{4}$ ). A rough sketch of it is published by $\mathrm{S}$. Reinach in the same journal for $1884^{5}$ ). An Egyptian statuette of Isis was also found in this temple ${ }^{6}$ ).

It is possible that the vaós of Isis Nemesis was built from funds raised by subscription (Nikomedes II being one of the chief subscribers) and that it was not finished till the following year. Thus, while Kallimachos, son of Epikrates, of Leukonoe was epimeletes of Delos, a man from

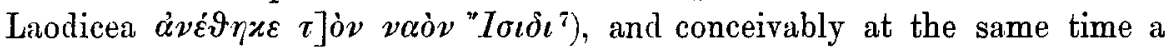
certain Menelaos, priest of Aphrodite? dedicated $\tau \dot{\partial} \nu \nu[\alpha o ́ \nu$ to [Sarapis] and Isis $^{8}$ ) and the other deities of the Egyptian group. The year of Kallimachos has not yet been determined - the first clue being that he was king-archon in $99 / 8^{\circ}$ ). I have conjectured that he belongs to $109 / 8$ for the following reason. In his year Euodos.... $\chi \varrho o v$ of Antioch was sacristan of the shrine of Aphrodite for the eighteenth time. We naturally think of eighteen successive years. In 107/6, however, Demetrios was sacristan ${ }^{10}$ ). Hence the term of Euodos must precede or follow this year. If it followed $107 / 6$, then his eighteenth term ${ }^{11}$ ) fell in $89 / 8$ or $88 / 7$ at the earliest und latest. The political situation, however, forbids us to think of a temple being constructed in Delos at this time. On the other hand, if we put Kallimachos in 109/8 - the first year prior to $107 / 6$ which lacks an epimeletes - Euodos began to serve in $127 / 6$ or $126 / 5$, according as we calculate exclusively or inclusively. I assume that Euodos secured his appointment as sacristan when the temple of Aphrodite was opened in 127/6.

The Sarapis-Aphrodite precinct was provided with several exedrae. A group was built as an appendage to the Sarapis temple by Staseas of Kolone, priest in 118/7 ${ }^{12}$ ). One was erected in the Aphrodite icoó $\nu$ by

1) This is inferred from the fact that the dedication was made ixis zov dinuov

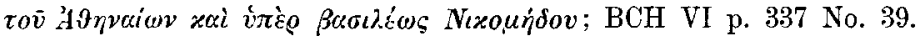

2) Or whatever this structure may have been. - 3) BCH VI Plate XI.

4) Pp. 304 and 308. - 5) P. 187. - 6) BCH VI pp. 304 f. and 313.

7) BCH VI p. 335 No. 35 ; cf. Ibid. p. 346 and XXVIII p. 151.

8) BCH VI p. 498 No. 7. - 9) Kirchner. PA No. 8021.

10) A $4 \dot{y} v$. IV pp. 461 and 462.

11) From Lebègue Rech. p. $142(c f .139)$ we learn that a certain Nikephoros was, sacristan of the temple of Zeus Kynthios for 37 times. Within his term Kointos of Azenia was epimeletes. - 12) $\mathrm{BCH}$ VI p. 320 No. 6 . 
Antiochos of Tyre in 109/8 ? ${ }^{1}$ ). Another was constructed by P. Aimulius L. f., a Roman, likewise for the Aphrodite precinct. The donor was at his akme in about 100 B.C. "). The epimeletes at the time of the gift was Andreas, son of Andreas, of the Peiraieus, a man who was herald of the Areopagos in 95/4. He was epimeletes perhaps in 104/3 $3^{3}$ ). Finally an exelrn was donated by Midas, son of Zenon, of Herakleia, the same who in the priesthood of Philoxenos of Sunion (98|7?) ${ }^{4}$ ) donated the mosaic pavement for the building marked $M$ on the plan of Hauvette-Besnault already referred to. The exedru was possibly the little odeion which stood directly opposite the mosaic ( $\mathrm{g} \mathrm{h}$ on the plan). It was probably made between $109 / 8$ and $104 / 3$, though only an examination of the extant ruins can determine this point definitely.

Apart from the exedrae of Staseas, a fountain, the gift of Dionysios of Sphettos. priest of Sarapis in 116/5, was the only work done ${ }^{5}$ ), so far as our record goes, between $127 / 6$ and $112 / 1$; for the residence of the therapeutai of Sarapis was given by two cousins. Lucius and [Decimus] Aimulius, whose alme belongs to about 130 B.C. $\left.{ }^{5}\right)$. It was, therefore, a product of the great building period $137 / 6$ to $127 / 6$ B. C. In 112/1 this house was finished up inside in fine style 7 , and two years later we have a notice of some similar decorative work ( $\ddot{\varepsilon} \nu$ ravoıs) being done on the house of the therapentai of Aphrodite ${ }^{8}$ ). A new period of activity openerl with the erection of the temple of Isis Nemesis in 110/9 and 109/8. Not simply was a subscription list started for the adornment of the shrine of

1) When Kallimachos was epimeletes. BCH VI p. $346 ;$ ef. p. 478 n. 2.

2) The genealogical tree may be constructed as follows:

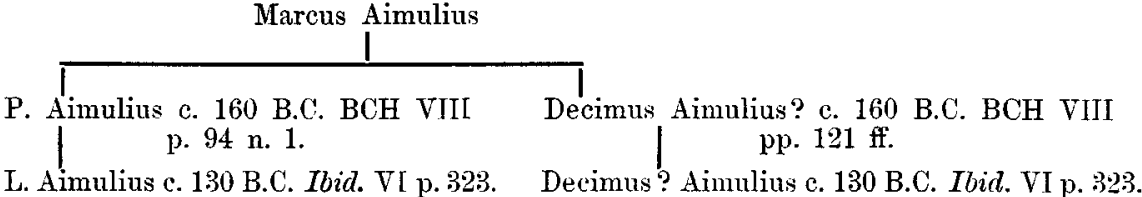

L. Aimulius c. 130 B.C. Ibid. V[ p. 323 .

P. Aimulius e. 70 B.C. Ibid. Ibid.

3) He came after 109/8, since Krates, not Euodos, was sacristan of the Aphrodite precinct. He does not belong to $96 / 5$, because of the priest of Aphrodite. After $96 / 5$ only the three archonships of Medeios are vacant, and it is unlikely that an exedra was built at that time. Moreover. the man was probably governor-general of Delos before he was herald of the Areopagos. Thus Pyrrhos of Lamptrai, herald of the Areopagos in $97 / 6$, had been epimeletes in $108 / 7$. It is clifficult to find any year but 104/3 which fulfils all the conditions. - 4) BCH VII p. 280 .

5) $\mathrm{BCH}$ VI p. 347. Of course. I leave simple dedications out of account.

6) $\mathrm{BCH}$ VI p. 323

7) A certain Theophilos of Antioch provided stucco for the priests' house. frescoing for the walls and ceiling, encaustic painting upon the doors, ends of beams upon the wall-plate, and the slab placed upon these. CIC II 2297.

8) $\mathrm{BCH}$ VI p. 489. 


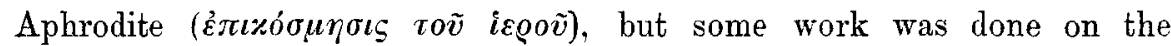

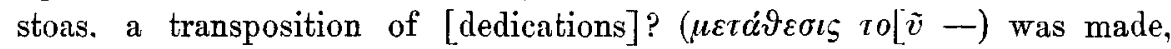
and a throne for the goddess was overlaid with gold ${ }^{1}$ ). At the same time pedestals were provided for statues which had probably lacked suitable positions ${ }^{2}$ ). The demos of Athens, too, yielding to repeated injunc-

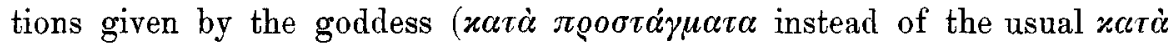
$\pi \varrho 0 \sigma \tau \alpha \gamma \mu \alpha$ ), made a donation to the shrine of Aphrodite through the

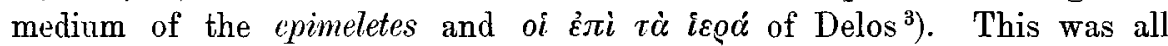
done in 110/9. In 107/6 Aphrodite received a new throne and a new altar $^{4}$ ), and in the years immediately following, her temple was decorated with pilasters and cupids ${ }^{5}$ ). The latter have been found and described by Hauvette-Besnault in BCH VI pp. $306 \mathrm{f}$. In 106/5? a portiım and pavement were placed in front of the temple of Isis Nemesis ${ }^{6}$ ): in 105/4 arcades, altars, and an approach to the precinct were built ${ }^{7}$ ), and in 103/2? the whole was finished off with pylons ${ }^{8}$ ). At a slightly later date retaining walls and a stairway $\ddot{\varepsilon} \omega \varsigma \tau o \tilde{v} \nu \alpha o \tilde{v}$ closed operations on the temple of Isis Nemesis ${ }^{9}$ ).

Upon the slopes of the hill on the other side of the Inopos ravine, directly opposite the precinct of Sarapis-Aphrodite, stood another ic@or in which were at least three temples ${ }^{10}$ ). One of these. as yet seemingly undiscovered, was the Herakleion, and provision made in 159/8 that an inscription should be placed in it proves its relative age ${ }^{11}$ ). The second was that of the Great Deities, Dioskuri, and Kabiri. Of this S. Reinach has found the ruins. From it have come few dedications, and of the four inscriptions taken from the vicinity two belong prior to $\left.137 / 6^{12}\right)$ : the others date from $128 / 7$ and $114 / 3^{13}$ ). It would seem, therefore, that this part of the region devoted to the foreign deities was equipped before the work was begun on the terrace or the other side of the ravine; for the only objects located in the Sarapis-Aphrodite precinct which belong earlier than $137 / 6$ are some vaults or arcades $\left.(\psi \alpha \lambda i \delta \varepsilon \varsigma)^{14}\right)$; erected to Aphrodite by the priest and the therapentai in 141/0. Then, while the building up of the adjacent precinct was in progress, the icoó $\nu$ of the Great Deities was apparently neglected. This neglect, however, may be only apparent and due simply to the deficiency of our knowledge. At any rate, after

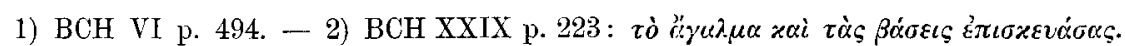

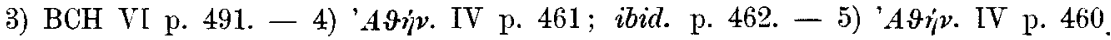

6) $\mathrm{BCH}$ VI p. 346 ; cf. below p. 231 . - 7) BCH VII p. 368.

8) $\mathrm{BCH}$ VI p. 322 No. 11 : the priest was Athenagoras of Kephisia. In 'A $9 \dot{y} \boldsymbol{v}$.

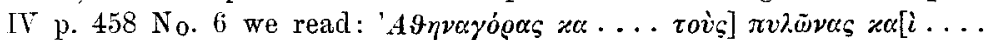

9) $\mathrm{BCH}$ VI p. 330 . The date is purely conjectural.

10) $\mathrm{BCH}$ VII pp. $329 \mathrm{ff}$; ef. Carte archiologique de l'ile de Délos by Ardaillon and Couvert. Bibliothèque des écoles françaises: Appendix I 1902.

11) CIG II 2270. - 12) We have assigned them in the table to $147 / 6$ and $144 / 3$.

13) CIG II 2996 and BCH VII p. 339. - 14) BCH VI p. 491. 
the second period of activity in the shrine of Aphrodite-Sarapis had come to a close (110/9-103/2?), Helianax, the son of Asklepiodoros, erected a third temple on the other side of the Inopos, 101/0 ${ }^{1}$ ). The fact that this man was priest of Poseidon Aisios for life indicates the deity which it housed. That he associated with this charge that of priest of the Great Deities ${ }^{2}$ ) shows hat Poseidon Aisios was taken into their cult. This is the temple from which have come curious medallions, within which were set portrait busts of many contemporary kings and courtiers.

5. The Priests of Sarapis. It is thus clear that building operations began in earnest in the precinct of Sarapis about thirty years after the Athenians took possession of Delos. The foreign colony had to grow before the turn of the foreign gods came. On the other hand there is no evidence for the maintenance of the cult of the oriental deities after 88 B.C. The Egyptian and Syrian settlement was probably broken up at that time. Hence place must be sought for priests of Sarapis, in whose years dedications were made to the shrine on the Inopos ravine, preferably between 140 and 88 B. C.

The following ${ }^{3}$ ) are not yet dated:

1 Theomnestos, son of Theogenes, of Kydathenaion

2 Apollodoros, son of Apollodoros, of Kropidai Athenagoras, son of Diokles

3 Athenagoras, son of -elen-, of Kephisia

4 Leon, son of Agatharchos, of Marathon

5 Kydenor, son of Dionysios, of Melite

6 Philoxenos, son of Philoxenos, of Sunion

7 Athenades, son of Diogenes?, of Kydathenaion

8 Zenon, son of Dioskurides, of Lamptrai

9 Markos of Eleusis ${ }^{4}$ )

10 Aristeas, son of Aristeas, of Marathon

11, 12 Philokrates, son of Philokrates (twice).

This list may be reduced somewhat. Thus it is not clear that Athenagoras, son of Diokles ${ }^{5}$ ), was a priest of Sarapis: he may have been priest of some other deity. He probably should not be identified with ' $A$...

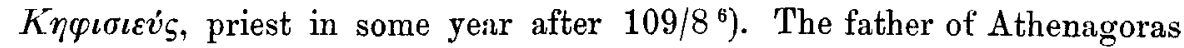
$K \eta \varphi \iota \sigma \iota \varepsilon \dot{w}_{\zeta}$ of BCH VI p. 347, who is doubtless the same as the priest

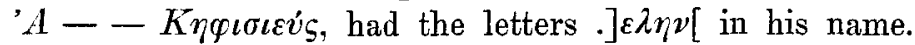

Markos of Eleusis made a dedication as priest to Ammon on behalf

1) $\mathrm{BCH}$ VII p. 364. - 2) Ibid. p. 349.

3) For the references see Kirchner, Prosopographia Attica.

4) BCH VI p. 342. All the Móozol (Mcćozor) are omitted in the Prosopographia also the Athenians found in the small group of inscriptions published by Homolle in Mon. Gr. 8 (1879) pp. $37 \mathrm{ff}$.

5) CIG II $2301 .-6) \mathrm{BCH}$ VI p. 323. 
of the Egyptian king Ptolemy Soter II. The inscription was found in the precinet of Sarapis-Aphrodite. Markos was probably a priest of Sarapis.

It is possible that Aristeas of Marathon was a priest of Aphrodite or the Great Deities ${ }^{1}$ ) since there is nothing whatever to connect him with Sarapis. Still, it is better not to exclude him altogether from consideration here.

Since all the priests listed above must precede $137 / 6$ or follow $108 / 7$, it should not be difficult to decide in which neighborhood to locate them. None the less, it happens in several instances that the internal evidence is ambiguous, so that the final judgment will have to be made on the basis of the lettering.

Theomnestos of Kydathenaion was priest of Artemis in 101/0 2 ). $\mathrm{He}$ probably held the lesser priestship earlier - hence on the criterion of the tribe he is assigned to $107 / 6$.

Apollodoros of Kropidai belongs to the period after 108/7, because of the other connections in which we find mention of Poseidonios, the son of Gerostratos, lileiduch in his priestship ${ }^{3}$ ). Since the tribe admits of so doing, I have placed him in $106 / 5$.

Athenagoras of Kephisia was in office later than Dionysios, son of Zenon, of Kephisia $(109 / 8)^{4}$ ). I have put him in $103 / 2$, because he held office after $109 / 8$ by only a short interval, and because it is conceivable that the priest for $109 / 8$ should have made a belated dedication upon the change of government in 103/2.

The genealogical tree of Athenagoras of Melite shows that Kydenor of Melite belongs after 108/7:

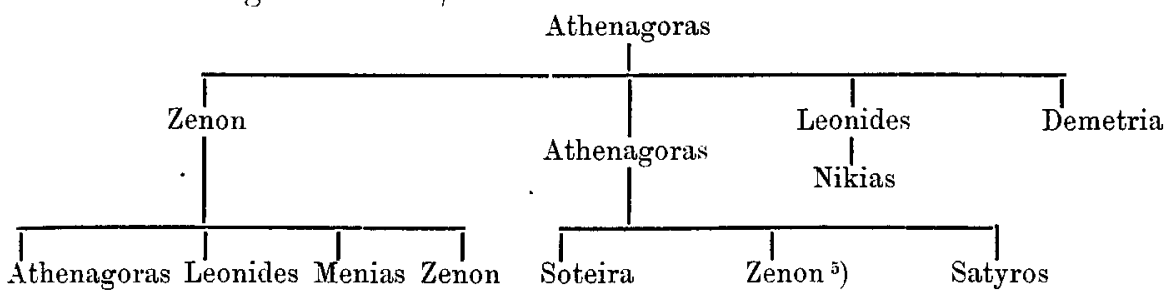

In $141 / 0$ a dedication was made to Leonides, son of Athenagoras, by his sister and brothers, Athenagoras being among the latter ${ }^{6}$ ). Athenagoras, son of Athenagoras, was priest of Sarapis in 126/5 ). To him a statue was erected by his three nephews in the priestship of Kydenor ${ }^{8}$ ).

1) Kirchner, PA No. 1678 (Ephebe in 107/6 B.C.) and No. 12304. where an inscription is republished from ' $A \vartheta \eta \eta v$. III p. 653 No. 15.

2) Kirchner, PA No. 6968. - 3) See above p. 226.

4) Kirchner, Gött. gel. Anz. 1900 p. 472.

5) Zenon and Satyros, sons of Athenagoras, of Melite are to be added to the genealogical tree in the Prosopographia (No. 217) from Mon. Grecs 8 (1879) p. 41 No. 4. Along with their sister they erected a statue of their mother. the daughter of Satyros, son of Hermokrates, of Auridai? (PA No. $11834 \mathrm{f}$ ) in 108/7.

6) $\mathrm{BCH}$ I p. $88 .-7)$ BCH XVII p. $147 .-8)$ ' $A \vartheta \dot{\eta} \nu$. IV p. 458. 
Supposing Athenagoras to have been twenty-five in $141 / 0$, he was 40 in $126 / 5$, and 67 in $99 / 8$, in which year we have provisionally placed Kydenor. Moreover, a second statue, erected in honor of Athenagoras by his nephews Menias and Zenon, was made by the sculptor Eutychides ${ }^{1}$ ). This man was working in Delos between $116 / 5$ and $95 / 4^{2}$ ).

In the year in which Athenades of Kydathenaion was priest Menodoros, son of Phainandros, of Mallos was working in Delos as a sculptor ${ }^{3}$ ). This same Menodoros made a statue which was erected at Delos in $97 / 6^{4}$ ).

Markos of Eleusis was priest while Soter II and Alexander I were rivals for the throne of Egypt. $108-88$ B. C. $\left.{ }^{5}\right)$.

Philokrates was priest when it was permissable for a man to hold the same civil office twice, $103 / 2-88 / 7$ B.C. ${ }^{6}$ ).

For two other of the dozen priests no prosopographical data exist, Zenon of Lamptrai and Philoxenos of Sunion. In Zenon's priesthood a

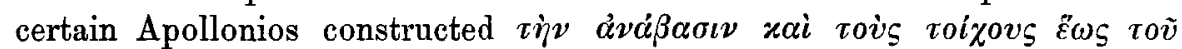
vaov. The dedicatory inscription was cut upon the steps which. from their position when found, had obviously led up to the temple of Isis ${ }^{7}$ ) that marked behind RS on the French plan. Whether this was the temple of Isis erected in $129 / 8$ or, as we have conjectured ${ }^{8}$ ), the one of Isis Nemesis given by Nikomedes II in 110/9, Zenon was priest after 108/7. Perhaps it was his grandfather who made a subscription in $183 / 2^{9}$ ).

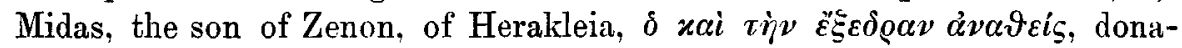
ted the pavement for the floor of the building marked M on HanvetteBesnault's plan, and immortalized his gift by inserting his name in the mosaic itself ${ }^{10}$ ). Only autopsy can determine the relative age of this

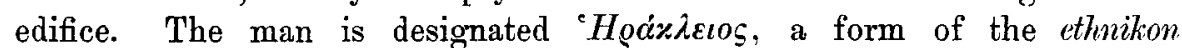
found in dated examples only at the time of the artists Lysippos, Eutychides, and Agasias, $116-88$ B. C. ${ }^{11}$ ). Since, moreover, the. fine mosaic was probably not put into a building prior to the development of the precinct in 137/6 ff., we are justified in locating Philoxenos after 108/7.

1) BCH IV p. 222.

2) Loewy, Insch. griech. Bild. pp. 180 ff.; cf. BCH XVIII pp. 336 f. Loewy, No. 244 belongs to $108 / 7$; No. 245 to $116 / 5$ : No. 246 to $106 / 5$ : No. 247 to $95 / 4$, and No. 248 to an uncertain year. The other statues by Eutychides cannot be dated. The priest of Sarapis dates 244 and 245. In 246 Zenon, the son of Zenon, is designated „pythaïstes in Athens": from BCH XXX p. 197 we learn that Zenon was pythaïstes in $106 / 5$. For the date of No. 247 see above p. 225.

3) $\mathrm{BCH}$ VI p. 322 ; cf. VIII p. 135 n. $2 .-4) \mathrm{BCH}$ VII p. 13.

5) Dittenberger, OGIS No. 170 n. 2. -6) Klio IV pp. 3 f.

7) BCH VI p. 330 Nos. 25 and 24.

8) See above p. 227. - 9) Kirchner, PA No. 6214.

10) $\mathrm{BCH}$ VI p. 305 ; VII p. 280.

11) BCH VII p. $373=$ VIII p. 488 ; XXIII p. 68 ; VIII pp. 143 and $146 ;$ XI pp. 260 and 270; but cf. Archiv f. Papyrusforsch. IV. 1907, p. 238. 
Leon, son of Agatharchos, of Marathon alone remains ${ }^{1}$ ). In BCH XXIII p. 66 is published the name of an epimeletes of Delos from apparently about 95 B. C., "A priest is perhaps the father of this officer, but not if Kirchner's restoration $\left.{ }^{2}\right)$ of the deme name, ' $A\left[\varrho \alpha \varphi \eta^{\prime}\right] \nu[\iota] o[s]$, is correct. We have assigned Leon in a provisional way to $102 / 1$. If we accept the restoration Marctthomios, it would be perhaps more satisfactory to place him in the period before $137 / 6, i . e$. in 148/7; but since no other dedication to Sarapis found on the Inopos terrace antedates $136 / 5$, and since an Italian, Quintus Gaii f., was the author of this one, I have preferred to think of Leon as obtaining the priestship in his old age, and of his son as reaching the highest office in Delos about twelve years later $\left.{ }^{3}\right)$. Since the $\varkappa о н \pi \varepsilon \tau \alpha \lambda \iota \alpha \sigma \tau \alpha i$ disappear with the sack of Delos in $88^{4}$ ), but are still found in the epimeleir of Aropos ${ }^{5}$ ), it is illegitimate to descend farther than $89 / 8$ with this epimeletes.

The stone on which are inscribed the fasti of the temple of Sarapis at Delos has been described very inadequately by the scholars who found and edited it. But from the brief note given by Hauvette-Besnault in BCH VI p. 350 we may infer that the fasti ended with the name of Sosion of Oinoe in 110/9. Since this was the time at which the official order of the priests of Aphrodite ceased to exist ${ }^{6}$ ), we are justified in surmising that some noteworthy event in this shrine also took place then.

M. Homolle has said nothing about the condition of the stone at the point where the extant list of priests begins. He simply prints the names as follows ${ }^{7}$ ):

\begin{tabular}{|c|c|}
\hline TIMI & {$[T] \iota \mu$} \\
\hline$\triangle H M O \Sigma I($ & $\Delta \eta \eta_{\mu} \dot{\sigma} \sigma \iota[\sigma \varsigma]$ \\
\hline$\triangle H M O \Sigma I O$ & $\Delta \eta \mu o ́ \sigma \iota s[\mathrm{~s}]$ \\
\hline$\Phi A N O B I O \triangle E A E Y \triangle I N I O$ & 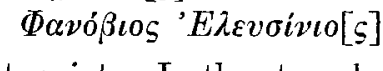 \\
\hline
\end{tabular}

We are left in doubt on many important points. Is the stone broken off above $[T] \iota \mu \ldots$, or were no other names there originally? Did proper names, now lost, follow Aquóros in lines 2 and 3? Does the list form a column at the left side or in the middle of the stone? Until these questions are answered our inferences must remain somewhat uncertain.

Demosios is not an Attic proper name ${ }^{8}$ ): it is the title of a public slave. Hence whether we are at the beginning of a list, or at its middle, the insertion of two extraneous titles at the point just prior to $137 / 6$ (the year of Phanobios of Eleusis) shows that something abnormal took

1) $\mathrm{BCH}$ VI p. 325. - 2) PA No. 2244

3) Thus Sokrates and Aristion of Oion, father and son. were epimeletai. the one in $105 / 4$, the other in $95 / 4$.

4) BCH XXIII p. 73. - 5) Ibid. p. 66. - 6) See above p. 219.

7) $\mathrm{BCH}$ XVII p. $146 .-8$ ) See the Prosopographia Attica. 
place at that time. The mention of two demosioi in connection with a temple document suggests a commission of some sort, for public works, or, still more likely, for the classification of dedications ${ }^{1}$ ). Since the temple of Sarapis was formally opened in $135 / 4$ it is probable that this commission? had something to do with the building of the edifice, or, perhaps preferably, with the transfer of dedications from an older shrine. After the enumeration of the commissioners? and the remosioi the list of priests was begun, or continued, with the names of those who held office during the building of the new temple and afterwards. It ended in 110/9. This was the year in which the temple of Isis Nemesis was erected, and, as has been pointed out already, it was the year in which a general repair and reorganization of the shrine of Aphrodite was made. It was the opening of a new period of building activity for the whole precinct. Part of the work of $110 / 9$ was to hunt out and arrange in chronological order the names of the priests of Sarapis who had served prior to the opening of the new Isis temple, perhaps from the Athenian occupation of Delos on, but more likely from the construction of the temple of Sarapis on the banks of the Inopos. The list ended in 110/9 because that was the year of its compilation, and it was compiled at that time because the re-arrangement of the dedications consequent upon the opening of a new temple showed the need of publishing the fiasti. The reorganization of the Aphrodite precinet was accompanied by a change in the mode of electing the priest. the official rotation of the tribes being abandoned ${ }^{2}$ ). A similiar alteration was made in the method of designating the priest of Sarapis - but not until 103/2. That there were special reasons for the abandonment in Delos of time-honored Athenian usages we shall now proceed to make clear.

6. The Dissolution of the Kleruchy. The Delian year began at the winter $\left.{ }^{3}\right)$, the Attic year at the summer solstice. Since the Athenians received Delos in the winter of the Attic year $167 / 6^{4}$ ), it is likely that their government was established at the end of the Delian year 167. The magistrates sent by Athens to manage affairs on the island came thus into control witbout any violent interruption of business, or distur bance of contracts ${ }^{5}$ ). Athenian simply took the place of Delian officials and everything went on as before.

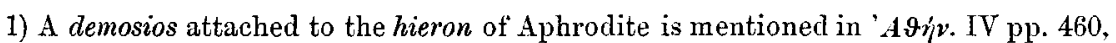
$462(107 / 6-105 / 4)$. I believe that no reference to one for the shrine of Sarapis is extant. For demosioi in connection with building operations see IG II $\boldsymbol{A} d d$. $834 \mathrm{~b}$ and c; II 5 $834 \mathrm{~b}$ : in connection with classification of dedications IG II 403, 404, 839, 840 etc. The temple and treasury commissioners at Delos had a demosios; BCH XIII p. 426.

2) It may have been abandoned in $109 / 8$, that being the last year of a rotationperiod. - 3) Homolle, BCH V pp 25 ff.; XXVII p. 63 n. 1.

4) Niese, Gesch. d. griech. u. maked. Staaten III p. 189.

5) BCH IV pp. $182 \mathrm{ff}$. (Maturing of loans made under the Delian regime); XXIX pp. 582 ff., esp. p. 557 (Reappearance of articles found in Delian catalogues). 
Thus the epimeletes superceded the Delian archon as governor-general and special eponymous magistrate of the island. In the place of the four hieropoio ${ }^{1}$ ) who had managed the temples and the moneys came a commission of four Athenians composed of two sections of two officials each,

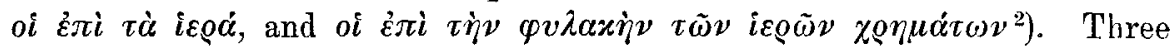
Athenian agoranomo ${ }^{3}$ ) took the place of three Delian agoranomoi ${ }^{4}$ ). An Athenian gymnasiarch came and took charge of the Delian gymnasium. To each of the temples came an Athenian priest instead of a Delian priest, the kleiduclss and kanephoroi becoming Athenian where such subordinates were needed. The natives were retained only as sacristans.

The Delians had been essentially parasites of the temple. Now that the honors and profits of the religious charge were taken from them, and the Athenians were not disposed to retain them on the island as laborers and souvenir makers and vendors, they had practically nothing to do. Accordingly, the government of Athens, drove them out altogether, and sent a colony of its own citizens to take possession of Delos. The organization of this new settlement was determined in advance by traditional considerations: it could not be other than that of an Athenian kleruchy. Hence the Athenian immigrants, at the same time that they moved into the houses of the Delians, occupied their elkilesiasterion, and their council chamber. They established a little republic on the Athenian pattern, with a probuleutic senate, prytanies to dispatch business, and proedri to preside at the meetings of council and people. They had all the mechanism for local legislation, and they set about passing decrees and erecting monuments in honor of officials and benefactors of all kinds.

The republic, however, was deformed from the start. It had two organic weaknesses: it did not choose or control its own executive ${ }^{5}$ ), and its legislation was subject to revision by the mother state ${ }^{6}$ ). Its position was, in fact, that of the colonies in British North America prior to the concession of responsible government in 1841. We are told by Strabo ${ }^{7}$ ) that the Athenian administration of Delos was efficient. There is, indeed, no evidence to the contrary, but we can be quite sure that there were

1) Homolle, BCH XIII p. 427; von Schoeffer, PW IV pp. $2486 \mathrm{f}$.

2) BCH XXIX p. 553 .

3) BCH XIII p. 410. The number was reduced to two between 155 and $151 / 0$ (BCH XVI p. 371; IG II 985 I E 36).

4) Von Schoeffer, loc. cit. p. 2488.

5) This results clearly from the documents published in BCH XIII p. 421; XVI p. 371 and p. 372; XIII p. 410; XVI pp 375 f., and from the list of subscribers IG II 985.

6) Doubted by von Schoeffer, PW IV p. 2497, but established by Francotte, La législation athénienne sur les distinctions honorifique et spécialement des decrets des clérouchies athéniennes relatifs à cet objet. Louvain, 1900.

7) $\mathrm{X}, 486$. 
frequent conflicts of opinion and authority between the local and the central government.

From $167 / 6$ to $131 / 0$ the republic just described operated normally. We have decrees extant at intervals throughout the entire period ${ }^{1}$ ). We hear of the boule and the prytanies, of ekklesia and elklesiasterion, of inscribing documents on stone tablets, of andit by Athenian jury courts, of forwarding documents to the Metroon, and of embassies going to and fro between the two communities. Then of a sudden it all comes to an end, and from Febry. of 131 there is no further intimation of the existence of a Greek republic on Delos. There are no more town meetings, and no more decrees. Even resolutions of private associations fail from this time on. At the same time, a new organism makes its appearance. From $126 / 5$ to $54 / 3$ the public activity of the island is incorporated, not as before in the Athenian colony, but in the aggregate of Athenians, Romans, Greeks and others both in permanent residence on the island and frequenting it as merchants and shippers. In other words. the Athenian kleruchy was dissolved and a multifarious assemblage of all the freemen who bappened to be on the island at the moment took its place ${ }^{2}$ ). Naturally, this heterogeneous body could not act as a miniature Athens: it could not take the place of a Lower House and pass measures along for ratification or rejection by the Athenian eklilesicr. It was in fact left without a political organization. We do not know how or when it met, or how it was managed when assembled. Its sole determinable function

1) $\mathrm{BCH}$ XXIX p. 199 (time of settlement): BCH X p. $36=$ XIII p. $245(165 / 4)$; BCH VIII pp. 121 f. (Synod of Melanephoroi? c. 160): CIG II 2270 (159/8); BCH XXIX p. 198 (?); BCH X p. 33 (154/3? Zaleukos) = XIII p. 410 (153/2 ?); CIG II 2271 (Synod of Tyrians 153/2); BCH X p. 38 (151/0?): BCH XXIX p. $196(151 / 0) ; \mathrm{BCH}$ XVI p. $371(151 / 0)$; BCH XIII p. $412(150 / 49)$; BCH XVI p. $372(150 / 49)$; BCH XIII p. $250(133 / 2)$; BCH XVI p. 375 (133/2); BCH XVI p. $376(132 / 1)$.

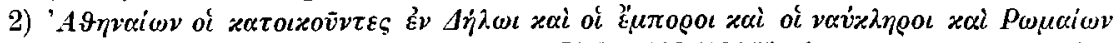

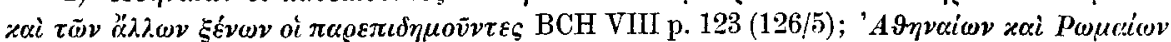

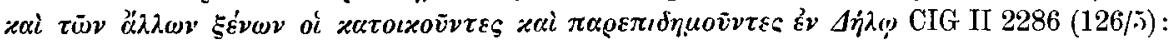
idem CIG II 2288 (-doros. son of Zenon, of Athmonon epimeletes); BCH XVI p. 152 (124/3); BCH III p. 371 (118/7); BCH IV p. 220 (c. 115) = XI p. 263 ?; BCH XI $p$. 262 ?; 'A

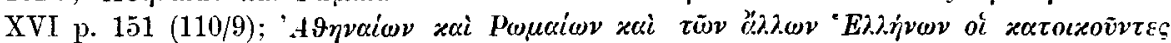

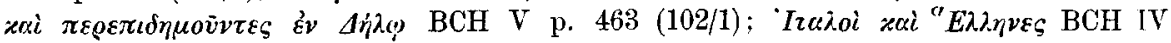
p. 219 (c. 102/1: different from the others prior to 88 both in formula and in that a Roman, not an Athenian magistrate, was honored by the assemblage); BCH X p. 37 (98/7); BCH XVI p. 150 (94/3). also metrically as below p. 240; BCH III p. 151 (Apollodoros archon c. 80 ); BCH III p. 156 (c. 80$)$; CIG II 2287 (54/3); BCH VIII p. 17; (Zenon, son of Zenon, of Marathon epimeletes c. 50); BCH XVI p. 157 (?); BCH IV p. 221 (?). A bilingual inscription of c. $80-78$ B.C. is as follows: Italicei et Graecei

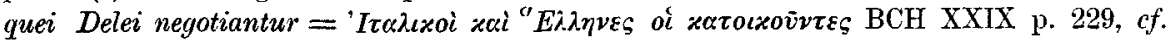
$\mathrm{BCH} I$ pp. $283 \mathrm{f}$. A latin inscription of about the same date runs thus: Plebs Atheniensis et Italicei et Graecei quei in insula negotiantur BCH III p. 147. 
was to record its appreciation of services rendered to itself by erecting statues or other monuments of the Athenian officials ${ }^{1}$ ). In this limited activity, however, it was unfettered by the legal disability of consulting the Athenians. It could, apparently, honor, or refuse to honor, its magistrates as it itself saw fit ${ }^{2}$ ).

The net result of this change was threefold. 1. The Athenian magistrates obtained a freer hand in administration through not being obliged to consult a local cliklesia. They could thus act more promptly and more vigorously. They were obliged, like the Roman proconsuls. to render an account only to a people among and over whom they did not serve ${ }^{3}$ ). 2. The community of Delos in its entirety obtained more liberty of action through being emancipated from the constant interference of the ekklesin in Athens. It could act quickly in a crisis without waiting for the Athenian government to give the word, and without fear of legal consequences. 3. The public life of the island was strengthened through the destruction of the exclusive privileges of the small colony of Athenians. The widening of the quasi-citizenship extended in like measure interest and responsibility in the affairs of the island. In particular, the influence of the solid settlement of Italians was enhanced, and in time they came to act as open masters of Delos ${ }^{4}$ ).

It is now necessary to ascertain the reasons for the dissolution of the kleruchy, and the formation of this hybrid body-politic. The ultimate cause was, of course, the enormous growth of the foreign population of Delos ${ }^{5}$ ). This made it increasingly difficult for the handful of Athenians to maintain their position and prestige, especially since the ,outlanders" were usually rich, or supported by wealthy corporations, or strong political interests. To this was added the chafing of the Athenian officialdom at the restraints of public control. Athens itself was becoming more and more aristocratic, and its rich men more and more contemptuous of democratic shibboleths. The pervasive influence of Roman opinion, moreover, was making for restrictions upon the power of the populace. Still, an occasion was necessary for the deposition of the kleruchs. entrenched as they were behind the breastworks of Athenian tradition. A successful

1) After 88 it conferred similar honors upon Romans.

2) For the procedure in case a club wished to erect a statue to an Athenian magistrate in Athens itself IG Il 47.) (112/1) is singularly instructive. In Delos after $131 / 0$ clubs, priests, private persons erected statues of Athenian magistrates when they pleased.

3) That is to the Athenians upon their return. After 11):3/? they did not have even this ordeal to face, Klio IV pp. $4 \mathrm{ff}$.

4) Athens joined Mithradates in 88: Delos supported Rome against Athens at the same time.

5) 20000 are said to have been slain by the general of Mithradates: Appian. Mith. 28 
attack must follow failure. Failure came in about $131 / 0$ B. C. It was the time of the slave revolts. Sicily had been the scene of a ferocious struggle. In various parts of Italy, and even in Rome itself, an uprising had taken place. Andronikos, the bastard son of Eumenes II, sought to retain his father's kingdom by summoning the slaves to his standards. Apparently the whole of the vast under-population of the ancient world was seething with sedition and aspiring to liberty, and by means of "underground railroads" communications were carried on between one slave centre and another. It thus happened that a revolt broke out in Delos and in Athens simultaneously ${ }^{1}$ ). In the latter place over a thousand men, probably in large part miners from Sunion, though all detailed information is lacking, tried to gain their freedom by force, and required the authorities to give their attention exclusively to the home danger. In Delos the slaves, we can well believe, were too many for the Athenian klernchs to cope with unaided. The whole free population was forced to unite in suppressing the outbreak. To be sure, the slaves were quickly beaten in both places, and the Roman government was not obliged to go to the aid of the local authorities as in the case of Sicily. But the entire population had of necessity to act in common to crush the insurrection. What more natural than that the body politic. created in the face of the gravest conceivable danger, should be perpetuated to prevent

1) The time is not, designated with any precision. Diodoros (XXXIV 2) simply mentions it while citing slave revolts contemporaneous with the "first" uprising in

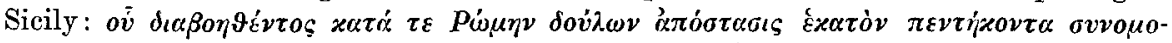

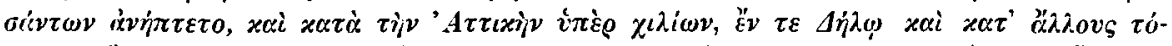

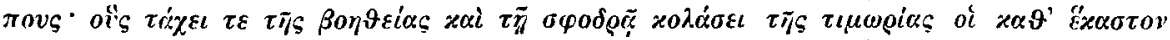

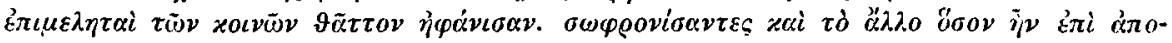
$\sigma \tau \dot{\alpha} \sigma \varepsilon l \mu \varepsilon \tau \varepsilon^{\prime} \omega \rho o v$. The outbreak of the servile troubles in Sicily he dates sixty years

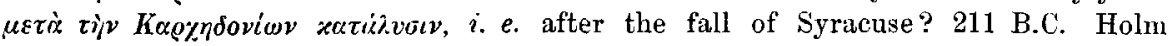
(Gesch. Sic. III p. 519 ff.) puts the beginning of the revolt in 139 and its end in 132. Diodoros defines the incident in a general way again in XXXIV 4: $\tau \dot{\delta} \pi \alpha \rho \alpha \pi \lambda \dot{\gamma} \sigma \iota 0 v$

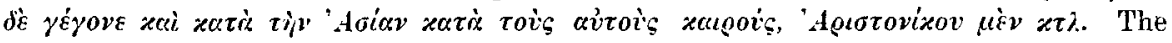
troubles with Aristonikos began in 133 and continued till 130.

The last Delian decree extant belongs to the year 133/2. but it received the sunction without comment of the Athenian ekliesia in Febry. of 131. This is the terminus post quem. The first extant dedication made by the new assemblage of the Delians dates from 126/5, but there is decisive evidence of the change from 127/6; for in this year occurs the first instance (BCH VIII p. 131 n. 2) of a dedication

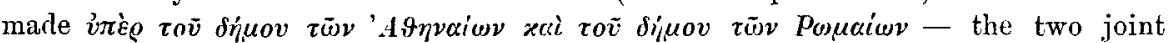
overlords of the island. From the fact that a temple was dedicated in the precinct of the foreign gods in $130 / 29$, two in $128 / 7$, and a fourth in 127/6, I im inclined to think of this building activity as subsequent to the slave revolt and a consequence of the dissolution of the kleruchy in 131/0. The absence of any reference to the kleruchy in the period 130/29-127/6, notwithstanding that it is richly represented by documents. confirms this opinion. The revolt probably took place immediately after the victory of Andronikos over Crassus in the spring of 130 (Niese. III p. 869). 
a recurrence of the peril? What more natural than that the leading men, both among the Romans and the Athenians, should think the moment opportune to suppress the local democracy? In Rome the senatorial reaction which followed the overthrow of the popular government of Tiberius Gracchus was at this time at its height.

The military coefficient of political equality did not prevail for long. In 131/0 the foreigners without regard to race or language had united to force the slaves back into their pens and subterraneous lodging places. And until 118/7 the $\xi \varepsilon \dot{\varepsilon} v o$, all alike, found recognition in the assemblage of the islanders. Then a distinction was drawn in the formula by which

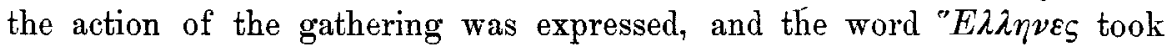
the place of $\left.\xi_{\varepsilon} \dot{\varepsilon} v \iota^{1}\right)$. The facts doubtless corresponded, and from this time on the three participators in the meetings are Athenians, Romans, and Greeks. The official preamble discloses few secrets ${ }^{2}$ ), but a metrical paraphrase of it is not equally discreet or reserved. Thus the following epigram 3), put upon a monument in honor of Aropos, governor-general of Delos in $94 / 3$ B. C.. lets ns see how frankly the Romans were recognized as masters of the island:

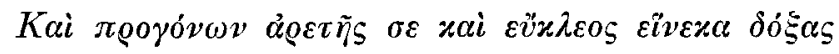

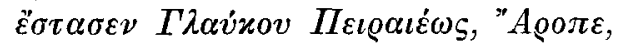

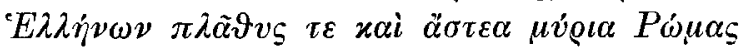

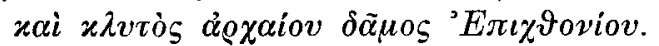

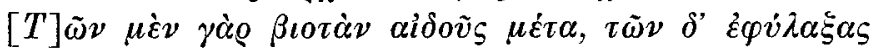

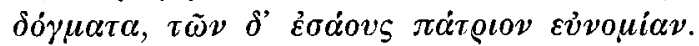

The three elements could, perhaps, act severally: but no case is extant in which the Athenians alone met in assembly. They were probably merged in the political organization of Athens itself ${ }^{4}$ ). If they substituted a koinon for a polity, all evidence to this effect is lacking. The Romans on the other hand, like the various groups of Greeks and foreigners, had their own national union and a splendid club room besides. This was the scene of a busy communal life; for the associations in Delos had, of course, freedom of meeting under the Athenian law promulgated in the first instance by Solon and finally tested in the case of the Peripatetic

1) See above p. 237 n. 1.

2) In 104/3, when three Cretan cities concluded to deposit at Delos a copy of in treaty negotiated between them, they made all their arrangements with the epimeletes (BCH III p. 293 ll. $15 \mathrm{ff}$.). The committee sent to the island to have the document inscribed on stone had nothing to do with a local $\pi$ ókı (Ibid. p. $29411.43 \mathrm{ff}$ ).

3) $\mathrm{BCH}$ XVI p. 150 .

4) Nothing betrays more clearly the consciousness of the Athenians that Delos was not theirs. but Rome's, than the frequency with which they designated themselves 'A $A \eta$ voio too, Athenians born on the island, who reached their 18 th year after $131 / 0$, did not always take pains to have themselves registered in their paternal demes. 
240 William Scott Ferguson, Researches in Athenian and Delian Documents. I.

School in $307 / 6$ B. C. But, as has been remarked already, no resolutions couched in the familiar terms of the Greek psephismata, like that of the Tyrian synod in 153/2 or of the synod of the nelanephoroi? of about the same time, are extant for the period after $131 / 0 \mathrm{~B}$. C.

The irresponsibility of the Athenian officials for the twelve months of their service on Delos bore its fruit in a recalcitrant attitude towards the strict control to which the magistracy was subjected at home, and, as I have pointed out in another connection ${ }^{1}$ ), it was from the circles officially connected with the administration of Delos that the oligarchic revolution of Athens in 103/2 B. C. issued. And doubtless in full consciousness of the precedent established, they chose the occasion of the slave revolt in Attica, when the miners at Laurium broke away from their guards, seized the fort at Sunion, and ravaged the country round about ${ }^{2}$ ), to effect a coup d'etat similar in its general effect upon the institutions of Athens to that which put an end to the Delian kleruchy in 131/0. The revolution in Athens was accompanied by changes in the administration of Delos to which reference will be made in another place. It did not affect in any way the composition of the assembly of the Delians. This remained the same in form, though in substance it was far from unfluctuating, till the agony of the civil war in Rome. Then in place of the composite formula there appears at the head of dedications

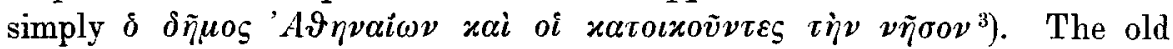
scheme appears for the last dated occasion in the archonship of Zenon (54/3 B. C.): the new one is first dated sharply in the time of Augustus, but it probably originated in some change of the status of Delos made by Pompey, Caesar, or Antony.

1) Klio IV pp. $10 \mathrm{ff}$.

2) Poseidonios in Athenaeus VI 272 e and f. The connection between the second slave revolt and the oligarchic revolution noted by me in Klio IV p. 12, was already surmised by S. Reinach in his work on Mithradates Eupator pp. $137 \mathrm{f}$.

3) BCH III p. 159 No. 7 ; cf. BCH VIII p. 154 (c. 44 B.C. ?); BCH III p. 159 No. 8; ef. BCH VIII p. 154 (same time?); BCH VIIl p. 154 (?); BCH XXVIII p. 148 (?); CIG II 2282 (43-27 B.C.); CIG II 2283 b (27 B.C.-14 A.D.); BCH II p. 399 No. 7 (27 B.C.-12 B.C. Pammenes priest of Apollo for life); BCH VIII p. 156 (same time); BCH III p. 162 (12 B.C.-14 A.D.); CIG II 2283 d (after 27 B.C.); BCH III p. $156=$ Rh. Mus. XLII p. 148 (Zenon, son of Pammenes, priest): BCH III p. 365 (4 B.C.-38 A.D.); BCH II p. 400 and III p. 161 (Clandius Emperor: Tib. Klandios Novios priest). 